\author{
SRĐAN D. MARKOVIĆ 1 \\ UNIVERSITY OF NIŠ \\ FACULTY OF ARTS \\ MARTA VUKOTIĆ LAZAR ${ }^{2}$ \\ UNIVERSITY OF PRIŠTINA WITH TEMPORARY HEAD-OFFICE \\ IN KosovsKa Mitrovica, FaculTy of PHILOSOPHY \\ DEPARTMENT OF HISTORY OF ART
}

\title{
MIRKO KUJAČIĆ AND SOCIAL ART IN SERBIA
}

ABSTRACT. The art of the fourth decade of the twentieth century which, as if it was announcing the World War II, was polarized between so-called "pure art" (l'art pour l'art), engaged art (l'art pour l'idée), and war realism. This separation often caused ideological conflicts that were intensifying and spreading into the sphere of political conflicts.

Two models of the leftist ideological concepts are reflected into the socially engaged artistic work of the two programmatically declared groups, which were devoted to an engaged form of artistic activity: the group "Earth" (1929-1935) from Zagreb and the group "Life" (1932-1940) from Belgrade.

Social art in Serbia had strong foundations in the second half of the third decade of the twentieth century and stretched throughout the period of war events until 1943. In the period between the two world wars it started with The Manifest of Mirko Kujačić, (1901-1987) published in 1932 and an exhibition of his surrealistic collages, framed shoes, an object named The Winter Motif and its counterpart, the painting named The Root of Belgrade Gentility. An important event for the continuation of such artistic tendencies was the forming of the group Life in 1934 in Belgrade, with Kujačić as one of the founders and the main protagonist.

KEYWORDS: Yugoslav modern art, social art, graphics, painting, "Life", "Earth", "Serbia".

\footnotetext{
magelen@mts.rs

marta.vukotic@gmail.com
}

This paper is a part of a research project Serbian Art of the 20th Century: National and Europe (OI177013) financed by the Ministry of Education, Science and Technologic Development of the Republic of Serbia. 
The global economic crisis, triggered by a fall in prices on the American stock market in September 1929, destabilized the world and the European political system, thus making a negative impact on the area of newly formed Kingdom of Serbs, Croats, and Slovenes (SCS), later The Kingdom of Yugoslavia. During the twenties and thirties of the twentieth century, the Kingdom positioned itself among the countries that had reoriented into market liberal societies after the World War I, such as: France, England, Czechoslovakia, and Weimar Germany. In this way, it found itself between the right totalitarian systems: Fascist Italy and then Nazi Germany, and leftist societies such as USSR. As a leftist totalitarian society, USSR submitted the principles of the liberal market and individual human and citizen freedom to planning market and class privileges, while the individual was losing their positions. The late twenties and thirties of the twentieth century in USSR marked a centralized party formation of all aspects of the life of the "working class avant-garde", where the leader of the Communist Party was elevated to the level of the cult personality (Šuvaković 2012, pp. 41).

Faced with the dissapointing expectations, immediately after the World War I, that the freedom would bring them prosperity, as a reward for a deserved and important role they had in the events related to the creation of a newly founded state of equal nations and nationalities, the peasants and the working class felt betrayed. They returned from the war, wounded, bitter, and deeply dissapointed. Everything they believed while fighting was, unfortunately, a deception prepared by war profiteers, deserters who did not even feel the horrors of the war, the crossing of the Albanian gulches, and life without homeland. Heroes of the war encountered poverty and humiliation directly from those for whose interests they had fought. It is logical that in the atmosphere of failed hopes in better and more just life there was an urge for rebellion and resistance, both among workers and peasants, but also among the part of the inteligentsia and artists, in particular the artists. For, the creator, in principle, cannot live and create beyond the time in which they exists. They, therefore, partly critically speak about the bitter doom, by not accepting the time which was given to them to live in. The creator, partly as a socially engaged artist, strives to point out the absurdity of some "new rules" in the society, labeling them 
through painting, writing, insisting to make people mull over what yesterday's warriors and heroes - who spend their last days in piteous settlements on the outskirts of big cities, in constant anxiety, fear, and concern over what tomorrow has in store for them-truly need. Therefore their turning to the influences of the ideas of equality advocated by the October Revolution seems logical.

In the Kingdom of SCS, under the influence of the October ideas, begins the creation of revolutionary cores in the wing of social-democratic organizations, which played an important role in the development of the labor movement and the idea of creating a unique labor party. The Communist Party of Yugoslavia was founded at a Congress in Belgrade in April 1919, in the hotel "Slavija", under the name of Socialist Labor Party of Yugoslavia. It stood on revolutionary positions and joined the Third International. It was becoming more and more popular, and it made a great success in the general elections, so in 1920 it changed its name to the Communist Party of Yugoslavia. In fear of such power of the Communist Party, the Government in Belgrade proclaimed the Announcement, on December the $30^{\text {th }}, 1920$, banning any communist activity and organization; later the persecution was extended to the strongest syndical organizations and the Law on State Protection was also established (Dedijer 1972, pp. 431). Apart from the economic crisis, the country was facing the strike of the national movement and rising resistance of the communists. After the assassination of the Radić brothers in the Assembly, the King firmly opted for the absolutist reign without intermediary; he abolished the Vidovdan Constitution and dissolved the Assembly. Deprivation of basic rights, explained as the way of protection of the most vital national and state interests and the future of the country, caused numerous objections among the syndicalists, in schools and universities, as well as in the countryside, and the dissatisfaction was then publicly reported in the streets of the city.

\section{THE IMPACT OF POLITICS OVER THE CREATION OF SOCIAL ART IN SERBIA}

Belgrade set the stage for various political conflicts. The assassination in the Assembly on June 20,1928, the absolutism of Karađordević, the abolition of the Constitution (6/1/1929), the crisis of 
parliamentarianism, the ban of the parties and associations, the difficult position of workers and peasants, all of this conditioned the increasingly difficult position of artists in the country, therefore, in Serbia. The reputation of the Communist Party was getting more powerful in the intellectual circles. After two years of the sixth-of-January dictatorship the problems accumulated, and burning socio-political issues, especially those of national significance, gained increasingly alarming proportions, and as the solution it has been resorted to the proclaiming of the new Octroised Constitution 3/9/1931. In the year of 1931, shortly before the November elections in Belgrade, the first mass student demonstrations occurred under the auspices of the Communist Party, opening the gates to the creation of the national resistance and the Popular Front (Ćetković 1991, pp. 28-31). The demonstrations in Belgrade were met with sympathy and support from the citizens.

Revolutionary, socialist, proletarian art, viewed from the aspect of aesthetics during the October Revolution to Lenin's death, was not homogenous, nor was it distinguished by a homogenous normative aesthetics. It was appearing in the spectrum of different stylistic determinants, starting from cubism, futurism, artistic experiment to Proletkult. The beginnings of the "Revolutionary Art", "Left Art", or more precisely "Social Art", can be found in the enlightenment and the populist conception of art, which was conceived and developed under the auspices of the Bolshevik Party, and it was unequivocally presented in 1922 by the AHRR resolution (The Association of the Revolutionary Artists of Russia), where it was not difficult at all to see the ideas of the perpetrators and the striving for rehabilitation of such painting. A logical extension of such ideas in USSR is "The Second International Conference of Proletarian and Revolutionary Writers", held in Kharkov in 1930, when "The Resolution on Political and Creative Issues of the International Proletarian and Revolutionary Literature" was adopted, and new, unique party platform on the field of ideology and culture was established, together with declaring the social realism as the official proletarian aesthetics (Trifunović 1973, pp. 241).

Regardless of the fact that party platform had an uneven degree of acceptance, depending on the country-to-country differences, its theoretically specified doctrine demanded consistency and uniqueness in application. Left-oriented artists, striving to engage in artistic practice in order to critically review social realities, resorted to critical social and socialist realism, which ranged from 
the French art of the nineteenth century and the beginning of the twentieth century (cezzanism, postcubism, expressionism of forms, neoclassicism, and traditionalism), throughout the twentieth-century American, British, and German critical social art, then the New German Objectivity, to the Soviet social, and socialistic realism.

The phenomenon of the social realism differs from the emergence of the socialistic realism, which was dictated and normative and blindly sticking to the directives and principles of the party. Unlike it, the social realism, despite being founded on the figurative, is a way and a means by which can be pointed out to an unfair polarism within the society, hence its ideas are often identified with anarchism, the ideas of the Trotskyism, and even with the left-oriented engaged visions of the avant-garde (Dedić 2012, pp. 77-98).

Avant-garde art emerged on the territory of the Kingdom between 1918-1935 within specific avant-garde cultures, Serbian, Croatian, Bosnian-Herzegovinian, and Slovenian, and in the time of the transformation of the bourgeois society into "The Society of the mass mechanically-electric reproduction and communication", within the framework of modern art, culture and society, and, as Šuvaković states "as a radical, transgress and experimental artistic and cultural practice" (Šuvaković 2010, pp. 53 \& 63). It was a period of realisation of political and cultural idea of Yugoslavness, the community of South Slavic nations.

The art of the third decade of the twentieth century in the Kingdom of SCS positioned itself between avant-garde and traditionalism (dadaism, postcubism, expressionism of the form, l'esprit nouveau, etc.), and after that, in accordance with the need to declare itself in the direction of the "engaged art" it returned to the tradition and academism, which Nadežda Petrović, a Serbian and Slovenian impressionist, already abandoned at the beginning of the twentieth century.

Poet Avgustus Cesares stayed in the Soviet Union in the period of 1923 - 1924, and in "Literary Republic" from Zagreb he published the article "Modern Russian painters, Art in The Revolution and Abstraction in Art" in 1924. Kandinsky, Maljevic, Tatlin, where he wrote about the complexities and contradictions of "the socialist modernity" in USSR (Šuvaković 2010, pp. 69).

In the period from 1921 - 1932 the world of fine arts was designated in magazines as well, such as: "Svetokret", "Zenit", "Dada Tank", "Dada Jazz", "Dada Yok”, “Ut”, "Hipnos”, “50 in Europe”, 
"Rdeci Pilot", "The New Stage", "Tank", the almanacs "Impossible" and "Surrealism Here and Now". These magazines were not intended for literature only, but they were "intertextual and interpictural experimental creations" that created a "specific avant-garde model of textual-visual expression" (Šuvaković 2010, p. 72). Avant-garde fought for the autonomy of painting, sculpture, and graphic media, striving to create the notion of Yugoslav avant-garde (Dragan Aleksic), or the Balkan avant-garde (Ljubomir Micić), which it failed to accomplish, but its specificity could be recognized only in the domain of the intertextual, interpictural, and intermedial transgression of literature and media arts.

In Yugoslav avant-garde it is possible to talk about utopian ideas of the "total artwork" (gesamtkunstwerk) which came down to manifesto of attitudes and utopian projects (the new age of Mitrinović, barbarogeny and Micić's Balkanization of Europe as well as the Zenitism of Jo Klek), but also about the clashes of the avant-garde and modernists, zenitists and dadaists, zenitists and surrealists, avant-garde artists and socially engaged artists, the leftist intellectuals of The Party and non-party leftist intellectuals. Viewed from the ideological aspect, Yugoslav avant-garde was left-oriented, Marxist, and under the influence of the Party (Šuvaković 2010, p. 73).

The art of the fourth decade of the 20th century, which, as if it was announcing the Second World War, was polarized between the so called "Pure Art" (l'art pour l'art), the engaged art (l'art pour lidée) and combat realism. This separation was often the cause for the ideological conflicts that were intensified and crossed into the sphere of political conflicts (Protić 1971, pp. 7-13). The relation to fine arts, which was expressed in the Resolution of the Harkov Conference in 1930, significantly influenced Belgrade socially oriented critics and the art at the beginning of the fourth decade of the twentieth century. This conclusion is also based on the fact that Oto Bihalji Merin ${ }^{3}$ took part in the work of the Kharkov Conference, though officially as a member of the German delegation of writers, designated to be an intermediary between Yugoslavia and the Soviet Union, which was strongly felt in his exhibitions by art and among artists in Serbia after 1945. Merin's approach to the problems of visual art is dominated by the proclaimed axiological method of perfection, in the relationship between society and art. Art is the reflection of reality, and the artist is the one who is obliged to represent the historical reality to the audience, because it is 
reflected inside him and the Proletariat consciously participates in it. This unreserved acceptance of the Soviet variant of the socio-realistic doctrine (the thematic recipe and the means for its realization) pushed Yugoslav creativity into the waters of conformism and pedagogical-programmatic action, and in the period between the year 1945 and 1950 it was influenced by a part of what we consider by the term "evil doom" of the Soviet art (Marković 2009, pp. 19-20). That is the very reason why Oto Bihalji Merin is also considered one of the main intermediaries through whom the information about the Kharkov Conference and the content of the Kharkov Resolution arrived in Yugoslavia (Rozić 1983, pp. 227).

As the principle for its cultural policy the Communist Party of Yugoslavia also accepts the doctrine of the socialist realism, which is implemented in all fields of the cultural-artistic life with the support of the visual expression of its followers, protagonists and activists.

Numerous new magazines are being launched, such as "Stožer" (Belgrade 1930-1933), "Danas" (Zagreb, 1934), "Pečat" (Zagreb 1939-1940), "Literatura" (Zagreb, 1931-1933), "Our Reality”, "Life and Work", "Art and Criticism", NIN, "Workers'/Labor Papers", "Young Culture", books of social content were published, in a word the social engagement of the artist was becoming gradually more obvious.

In the area of fine arts that idea was born in the movement called "The Social Art". This movement, however, never reached uniqueness in both the aesthetic and ideological concept in the Kingdom of Yugoslavia.

3 In the early 1950s, at the time of break with social realism, Bihalji suddenly broke away into the group of modernists. In the book by Predrag J. Marković Belgrade between East and West (p. 420) there is a witty account of Bihalji's shift to the group of modernists. Namely, the story starts somewhat earlier and is related to the exhibition of four painters from the Soviet Union (Aleksandra Dejnek, Arkady Plastov, Aleksandar Gerasimov and Sergei Gerasimov, in August 1947 remark made by S. M.) in Belgrade, to which Bihalji led the whole "Borba" group, paying particular attention to "Gerasimov's painting The Kolkhoz Holiday, especially the young boy wearing a t-shirt and riding a bicycle, which he called ingenious. This story of Bihalj-Merin was written by Mihailo Lalić almost a decade later. What is interesting is Lalić's commentary on the modernist transformation of Bihalji: "It seemed to me that Oto Bihalji-Merin, by means of this Gerasimovean bicycle, had transferred from realism to modernism, from East Berlin to the West." 
After the Kharkov Conference and Breton's Second Manifesto (Breton 1979, pp. 57), the engaged art of the fourth decade of the twentieth century was joined by surrealists as well. Following the anniversary of Hegel's death, "Eleven Surrealists", the first of whom was A. Vučo, and the last M. Ristić, published a brochure in 1931, a kind of manifesto named "The Surrealist Position", which was made in 1930, in Belgrade. On this occasion and at that place, they declared themselves as the followers of those who wanted to actively participate in changing the social reality. The same year, "The Plan for One Phenomenology of the Irrational" by Marko Ristić and Koča Popović was published, where the relationship of the surrealist to the historical materialism was explained. The magazine "Surrealism Here and Now" was also published that year, which was shut down after the third issue, the same thing happened to the collective surrealist movement in Serbia (ćosić, 1969, pp. 25).

The idea of the social movement in literature at that time, which was crucial for the formation of ideological positions and painters of that time, was the concept within which the artistic practice takes an important role in shaping a new, free, and humane society. This lasted until the appearance of the magazine "Danas", which announced the collapse of the "social literature" by opening a new polemic circle in Serbian and Croatian media from the period of 1930-1933 (Tesic 1983, p. 929).

After the collapse, the surrealist group came to the left, although there were also heavy differences in the field of the theoretical thought and criticism: some were devoted followers of the politics of the Party in the domain of culture and art as well, while the others, by following Krleža's "Foreword to the Book of Drawings of Podravian Motifs by Krsta Hegedušić", suggested the synthesis of art and revolution, which started the conflict on the left (Lasic 1970 , p. 210-223).

\section{MIRKO KUJAČIĆ (1901-1987) HERALD OF SOCIAL ART IN SERBIA}

The art scene in which the social movement was active existed not only in the city of Belgrade, but it spread all over the country. It was an art that was interested in the poor, the lives of workers and 
peasants, the art that was growing next to the masses of people, in poor working-class suburbs, on construction sites, on the fields, etc. The social art deeply believed that it could contribute to the realization of the social justice, social changes to better, by the revolution and establishing the working-class authorities/power. By entering into the lives of workers and peasants, the artists brought art into their lives and life into art, as a signpost, as a social need, and as an integral and engaged part of the social struggle.

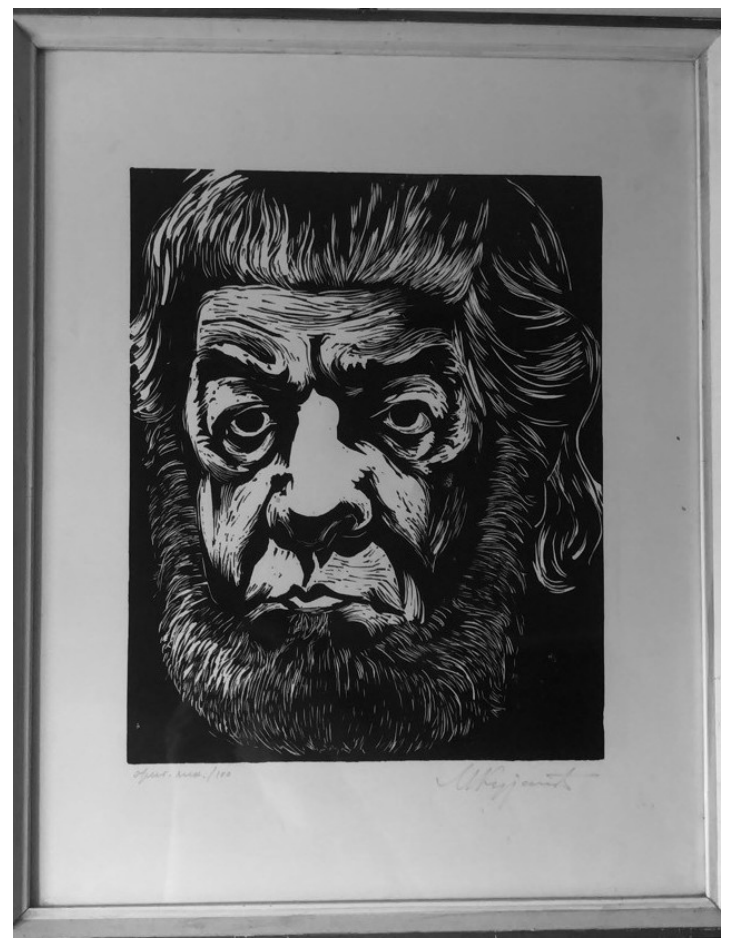

IMAGE 1. Mirko KuJAČíć, SELF-PORTRAIT, $46 \mathrm{X}$ 37, WOODPRINT, NOT DATED, PRIVATE PROPERTY.

Artists of the social tendencies in Serbia were primarily oriented toward Paris, then to the USSR, but also to the great names of German and Belgian social art. It is precisely in Kujačić's work, the woodprint "There is no such thing as a free lunch" from 1933 that, the influence of the North and Fiedler's, Riegl's and Worringer's theoretical and critical texts about the work of art as a product of the internal necessity, as the product of two principles that are related as correlation: the work of art as an expression of the artist's intention, on one side, and the work of art as the result of 
empathy on the other, can be clearly discerned. It is precisely Kujačićs close intimacy and understanding of the position of the disenfranchised and, at the same time, a harsh criticism of the ruling class which holds nothing sacred and has irrepressible thirst for wealth at all costs, which can be "read" in a complacent expression on the face of the exploiter and the position of his body, lolled in the armchair, while in the second plan of the statement factory halls can be seen, with illuminated windows and smoke that gushing out of the chimney points out to his relying on the ideology of the Western provenance social art, first of all to the artists gathered around the group "The New Reality", which, partly, arose from the creators that were gathered around the group "The Bridge", primarily George Grosz and Otto Dix.

The incentive that came from the USSR was emerging out of two conceptually separated and significantly different artistic ways: engaged painting of academic forms, such as the work of Boris Kustodiev, Aleksandr and Sergei Gerasimov, Aleksandr Dainek, Arkady Plastov, etc., and on the other side, from the wing of the Russian avant-garde, led by El Lissitzky, Vladimir Tatlin, Aleksandr Rodchenko, Aleksandr Vesnin, Kazimir Maljevich, etc., whose theoretically designed background had similar minds and followers among social artists in Serbia. The ways of art to which the Russian avant-garde gravitated in its revolutionary enthusiasm was best expressed by Vladimir Majakovski, advocating for the art that lives on the street, in squares, in factories, in working-class apartments, naming the streets "our brushes" and the squares "our pallets" (Mitrović 1983, p. 85). Except the influence from the USSR, the German social art was a great role model to the Yugoslav painters, especially Gross' art, which gained a distinguished place in the leftist press, where its sententiousness was praised and reduced to two words: "Fierce and Militant", but at the same time wrapped with the refined lyricism and intimistic processing.

Mirko Kujačić was, according to today's criteria, a multimedia artist of exceptional education, versatile talent, and culture. First he graduated from ballet-acting school, became a master of ballet (Ministry of Education led by B. Nušić and National Theater called a competition for education of young actors and masters of ballet in 1921), and then he started working in the National Theater in Belgrade. Klaudia Isachenko, one of many Russian refugees in Belgrade of that time, a teacher in the ballet-acting school and one of the founders of the Belgrade ballet (1919-1921), recognized the talent 
in that tall and lean young man, and then she tried to make Kujačić immediately get several roles as a ballet dancer and an actor. Relentless and rebellious in terms of spirit, unhappy with the entertaining part of the theater, as he used to say, he adamantly abandoned it, theatrically refusing to play the role of a priest, and then he wrote his resignation in a pathetic tone, where he stated his disappointment in the temple of the goddess Thalia, which was converted, as he stated, into a fairground and the actors into ordinary entertainers (Vukotić, 1985, pp. 26-28). ${ }^{4}$ That was a period when Kujačić chose fine arts. Primarily he was attracted to sculpture (Art School in Belgrade, Toma Rosandić, 1923), and then he opted for painting. The immediate reason for this was the wedding and the departure of Ivan Lučev to Paris, who was an excellent friend of his, and the student of Petar Dobrović at that time. Immediately after that, Kujačić applied for the French scholarship through the Ministry of Education, which he eventually received. He decided to share the scholarship with his colleague and friend Dragan Baja Beraković, with whom he went to Paris in Andre Lhote's studio (Studio A. Lotta, first stay 1926; second stay, 1960).

His stay in Andre Lhote's studio in 1926, his advice and, above all, the analysis of the work of classical and modern art, beneficially influenced Kujačić. It can be seen in his map graphics called "Fishermen", in purging and reducing the statement. The purging in terms of narration and reducing the composition to the basic dynamic structures, in which the body movement of the fishermen gathered around the crates of fish is wisely controlled and directed at the leash with the movements of other fishermen, which gradually increased the expression and achieved almost the Baroque strength of utterance without contact with narrativeness.

Regardless of the expression, in itself, which emerges from the relationship of black and white, the relationship that is appropriate to the graphics, Kujačić directed all the drawing skills toward the "disburdenment/relieving" of the utterance through the accentuated linear tremolo which restricts, almost sculptural form, of the fishermen gathered on the deck. The whole structure of human

4 M. Vukotić „Нова авангарда у старом закашњењу. Разговор са Мирком Кујачићем“ Титоград: ОВДЈЕ год. XVII ठр.198, Титоград, 26-28, 1985. M. Vukotić interviewed Mirko Kujačić in his home in Mostar, on the occasion of a retrospective exhibition held on the premises of Art Gallery in Mostar. The interview ran smoothly, simply and spontaneously. During this informal interview the artist answered as many as 50 questions, which were later edited and published. 
bodies located in a triangular spatial scheme was opposed by the stylized ornamental frieze of the rippling sea that touches the structure of the sky on the right side of the composition, through which he gained a rational and thoughtful utterance inspired by real life.

Unlike this utterance ("The Sun is scorching, the sardella must be brined") in the woodprint, from the same map, "They Raise Traps on the Hunting Grounds", Kujačić reduced the expression down to a minimum, primarily with the subtle linear "weaving" of the composition in the central part which is comprised of the fishermen's figures, placed in a triangular compositional scheme, who collect fish from the traps.

To that, in essence, calm and stabile composition, the movement and controlled expressive energy is given by acridly defined movements of the clouds and sea waves in the background.

But it seems that the influence of Andre Lhote and his theories is felt in one of his oils created around 1930. In this picture, which was Gromerly understood in the composition, also from the life of the fishermen, as if the most recent lessons of Lhote and interest in the scenes from everyday life, for introduction of the color and overcoming of the achromatic structure of orthodox cubism and for creation of deepened space within which the forms can develop freely.

Representatives of "Zenitism" and "Barbarogenia" were especially prominent in the design of Marko Kujačić's artistic world, which was greatly encouraged by his association with Branko Ve Poljanski and Ljubomir Mićić. In that period he was also signed as "Mir Barbar". One of many leftist activists' events bears witness to the association of Kujačić and Mićić, which was recorded by, at that time, agitated Belgrade daily press. That was about the "Open Letter to Rabindranath Tagore" printed as a flyer by Kujačić and Mićić, and then with a lot of theatricality and fighting spirit they were throwing it on the visitors of the "Kolarac's National University" in the crowded hall during Tagore's lecture on November 16, 1926. This action was preceded by loud shouting of the paroles such as "Down with Tagore!", "Long live Gandhi!" which was intended to draw attention of Gandhi's incarceration and that nothing was being done on this matter except some parlor lectures where the modern civilization was glorified, as they explained in the letter (Vukotić, 1985, pp. 26-28). ${ }^{5}$ 
Kujačić also cooperated with the "Cloud" group, which he considered to be contributing to the affirmation of the art creation freedom and the personal expression, but also in the "fight" for modern art in Yugoslavia, even though they were "l'art-pour-l'art-the-same".

In Paris, he was especially associated with Petar Palavicini, and an event from their socializing with Josephine Becker describes the turbulent and artistically interesting life, when, on the proposal of Petar Palavicini, they prepared a particular event (happening) in "Luxor" wine cellar in Paris, where, in banana skirts, a costume that Becker launched, in the spirit of her "Banana Dance" they played a surprise show picking up a loud applause along with her enthusiasm (Vukotić, 1985, pp. 26-28).

In contact with the representatives of the Yugoslav avant-garde, Paris, Lhote, as well as the leftists in Belgrade, he forms his political tendencies. Much of it came from his house. Kujačić's father, doctor by trade, whose house was a gathering place of the "clubbers" and "the righters"-the representatives of advanced ideas in Montenegro at that time-translated Tolstoy's "Social Position in Russia" at that time, and by the end of his life he even translated "Iliad" in decasyllabic (Ćetković, 1991, pp. 328).

\section{FIGHTING ARTISTIC PERFORMANCE OF MIRKO KUJAČIĆ ON APRIL 25, 1932 IN BELGRADE}

All these influences and events were so called "fighting guidelines", directed his "fighting artistic performance" on April 25, 1932 in Small Gallery of the Artistic Pavilion "Cvijeta Zuzorić", prepared by Mirko Kujačić himself, which today is an unavoidable event in the context of history of art in Serbia and Yugoslavia.

For this performance, Kujačić had been preparing for more than a year, tirelessly working in the studio of Ivo Seremet in 19 Jevremova St. in Belgrade (Vukotić, 1985, pp. 26-28). His intention was to separate himself from, as he used to say, artistically-individualistic

5 For more information please consult: $\Phi$. Мирски, „Индијски национализам. Поводом доласка г. Рабиндранат Тагоре“, Београд: Полийика 15.11.1926, Београд, 4; Аноним, „Рабиндранат Тагоре у Београду“, Београд: Полиӣика 16.11.1926, Београд, 5; Аноним, „Београђани одушевљено поздрављају великог индијског песника. Два предавања г. Рабиндраната Тагора“ “, Београд: Полиёика 17.11.1926, Београд, 6. 
and subjective contents, in favor of application of new, advanced leftist ideas of the social justice and concern for the poor. He did not manage to perform this immediately, not only because the work of Belgrade artists was founded on it, but also because he himself based his work on those tendencies (Trifunović, 1967, pp. 30, 431-432). The breach with that kind of art was seen in the theme that would "symbolically" talk about new ideas. In the studio, he started working on a female act, without the model, big dimensions, which he was working out in such a way that he turned it upside down, so that the head of the imaginary model was faced downwards. After that, he continued working on this act in a Belgrade slaughterhouse. Two poor boys and a colleague Žika Vlajnić helped him to relocate a large canvas, which no longer resembled an act, but a slaughtered bull, as well as painting equipment, around the slaughterhouse (Trifunović 1973, pp. 477). One of the boys was wearing ragged footwear from which one could see his frozen, muddy feet that at the same time inspired Kujačić to make a collage named "The Brogue". At the same time he continued to work on the big canvas for which he came to the slaughterhouse, in a place full of blood and slaughtered bulls. In such an atmosphere "The Skinned Bull" was made, in almost real dimensions, which was to be exhibited, next to the collage in "Cvijeta Zuzorić" in 1932.

In 1932 in Artistic Pavilion "Cvijeta Zuzorić", Mirko Kujačić performed a multi-layered "play" which can be classified as the predecessor of "happening" in Serbia. In front of a crowded gallery of Belgraders and other visitors, he first proclaimed his "Fighting Manifesto", theatrically standing in front of, for this occasion, his own socially engaged collages. For this occasion, he was purposely dressed, as a wage-worker from the street. Creased trousers and a blue-collar shirt more intensely underlined the importance of everything written in the "Manifesto", but also of everything created on the collages. Kujačić surprised even his closest associates and friends with his "warlike reading with ardor and pathos, the clenched fists and combat gesture" (Tešić 1983, p. 238). The Manifesto was read at a joint exhibit with Staša Belozanski, but whose works remained in the shadow of the unusual event organized for Belgrade audience by Kujačić (N.J. 1932, p. 7). Except the "Manifesto", the present met with two works, also unusual for the time and space in which they were created, with two surrealist collages: the first, where a torn brogue was nailed in a framed and painted white canvas, removed from the leg of one of the boys from the slaughter- 
house, which was captioned below as "Winter Motif". Reserved for the Museum of Humane Societies" and its counterpart, the second collage, with which, as he himself stated "something should be told to Belgraders". That was a smaller two-color painting, on which there was a (bunch) of leek with a caption underneath: "The Root of Belgrade Gentility" (Vukotić, 1985, pp. 26-28).

After presenting the "Manifesto", Kujačić set a stool in front of a large painting, oil painting, captioned "Skinned ox" and introduced the audience with the history of its creation. He then called his friend, Josip Kulundžić the director of the National Theater in Belgrade at that time ${ }^{6}$, to stand in front of the canvas and invite the audience, through the dialogue with the artist, to reveal what was the aim of the event. Since there was no discussion, Kujačić made a loud statement that he accepted silence as the approval of his "Manifesto" and everything else that was proclaimed at the exhibition. At the very end of this unbelievably visited exhibition in Belgrade, he added, with the same ardor and his unique theatricality, that from that day on he "rejects any further cooperation with art for art, because he does not want to "raise" his personality through art, but he puts his forehead, eye, and arm before human thought for poetry of progress, for a healthy man, for the fight against sanctified ideals, against the tradition, against eternal beauty [...]" (N.J. 1932, pp. 7).

"The Manifesto" and the surrealistic collages shadowed all previous opinions which he proclaimed in magazines "Time", "Politics", "Nin", etc., as an art critic and a theorist. However, this event, not even "The Manifesto" in which a typically leftist view on art was clearly exposed, did not encourage the critics of ancient and periodical press to comment, evaluate or criticize it, but everything went almost unnoticed, with the exception of several critics (Dragan Aleksić, Rastko Petrović) directed to Kujačić's painting (Rozić 1983, pp. 227-228).

Regardless of the cynicism of Rastko Petrović that a shoe with holes in it is well placed on the gray background of the woven cloth (Petrović, 1932, p. 7), Kujačić's closeness and knowledge of the events in European and world avant-garde art scene cannot be disputed today. This is related, above all, to Dishan's performances

6 Josip Kulundžić (1899-1970) Zemunac, who is little known, He was a founder of Department of Dramatic Arts in Belgrade and its first Professor, writer, director, theater pedagogist, theatre director in Croatian National Theater, Serbian National Theater in Novi Sad. 
within the framework of the Dada movement and exhibitions of the objects in the gallery space, that is, to attempt the redefining of the object according to oneself, the utility object, into the object as a work of art that is exhibited in the gallery space. But unlike Dishan's approach to a finished object without emotions and sentimentalism, which, by his choice, he elevates to the work of art, Kujačićs selection of the apprentice's torn shoes and the title of the work itself, "Winter Motif, 1932", clearly indicates his engagement and the need to speak to the extent of his own being through a concrete object that belongs to the misery and hopelessness of everyday life, rebelliously, romantically, and symbolically pointing to the misery and lowness of the world, with which he is faced as a creator and a humanist.

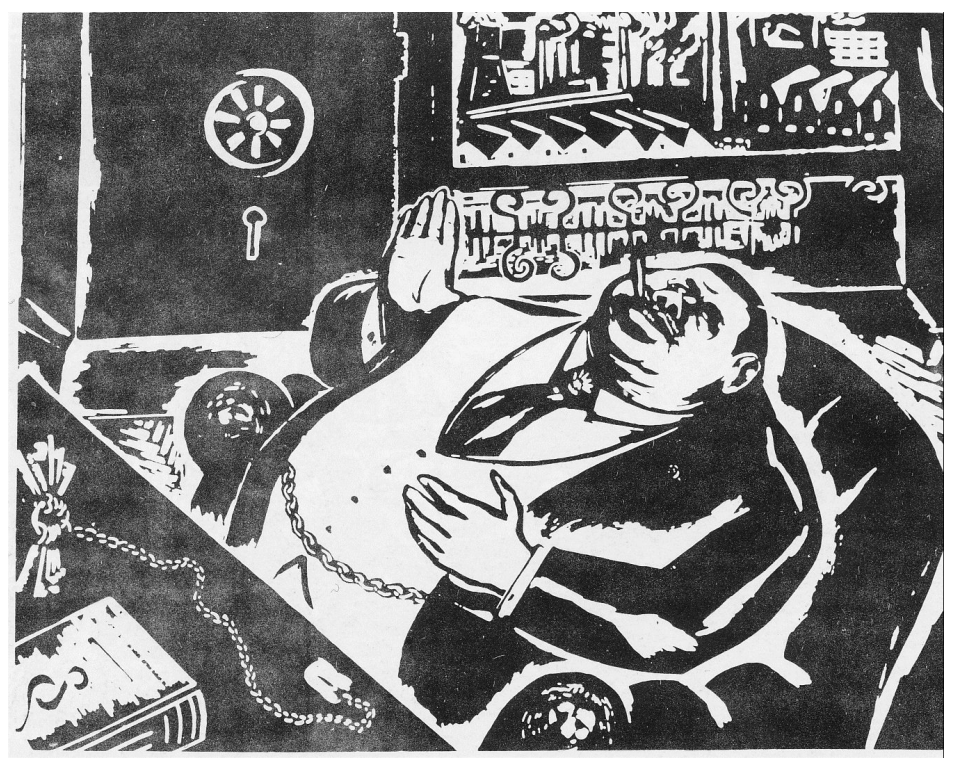

IMAGE NO. 2. MiRKO KUJAČIĆ, THERE IS NO SUCH THING AS A FREE LUNCH, 18,5 X 25, WOODPRINT, 1933, PRIVATE PROPERTY.

In the atmosphere of the changing autumn and spring exhibitions in the Art Pavilion "Cvijeta Zuzorić", Kujačić's exhibition came in like a bolt from the sky, like a rebellion, resistance, like a public invitation to protest, but also like a specific form of a preceding performative action or "happening", with which the life of the working class is introduced to the gallery, to the world of art, and social justice and rectitude are problematicized with it. For the first time in Serbian fine arts history a program of social art in such an 
original, strong and impressive way was exhibited. In essence, Kujačić was far more interested in proclaiming the studio-made spirit of protest and resistance in the gallery, on the street or in public, than constructing a new artistic utterance or aesthetics. Kujačić's work is the performance of production, the exchange and consumption of events, whose aim was to destabilize the contextual situation. This involved revising the function of the artwork by subjecting it to the excessive, experimental, and emancipatory artistic practice (Šuvaković, 2010, p. 281).

As a result of this event, as was Kujačić's exhibition in "Cvijeta Zuzorić", there was a demand, almost spontaneously, for the groups of artists to unite and to form a unique front of common "combat requirements" in a joint performance.

\section{MIRKO KUJAČIĆ AND THE APPEARANCE OF THE ARTISTIC GROUP “LIFE” (1935-1940)}

Between the work of surrealists and the appearance of the group "Life", social art in Serbia is in full swing after Kujačić's "Manifesto" that was devoted to "collective art of justice, sacrifice and brotherhood" (Ćetković, 1991, p. 48). The thing that follows, as the logical and unavoidable consequence of the "Manifesto" and the exhibition in "Cvijeta Zuzorić", is the formation of the group "Life" in 1934 in Belgrade whose founder and main protagonist, among others, was Kujačić himself. The group was formed in his apartment at the mansard in 6 Petrogradska St. in Belgrade. After several preparatory meetings, the group was formed, as Mirko Kujačić remembers, except him, by Đorđe Andrejević Kun, Radoica Živanović Noe, Dragan Baja Beraković, Josip Bepo Benković, Đurđe Todorović and Steva Bodnarov, although Todorović and Bodnarov, as Kujačić remembers, disagreed on the matter of presence on the first constitutive session of the group "Life". Exceptional importance of Đorđe Andrejević Kun for this artistic movement is accentuated in the technical literature, however, without denying that, Kujačić described him also as a quiet and taciturn man, who rarely spoke in the Group, while, as Kujačić remembers, Radoica Živanović Noe was the main theoretician in the Group, but also the main agitator together with Beraković and Kujačić (Vukotić, 1985, pp. 2628 ). The group that was soon joined by numerous artists of the 
same artistic orientation, including Moša Pijade, Bora Baruh, Pivo Karamatijević, etc., continued to meet regularly in 19 Jevremova St. in the studio of the sculptor Vladeta Piperski. "Life" was seen as an illegal group influenced by the Communist Party from the very beginning, which was one of the reasons that it had never had an independent exhibition of its own, but it only appeared within regular autumn and spring exhibitions and acted within the Society "Cvijeta Zuzorić".

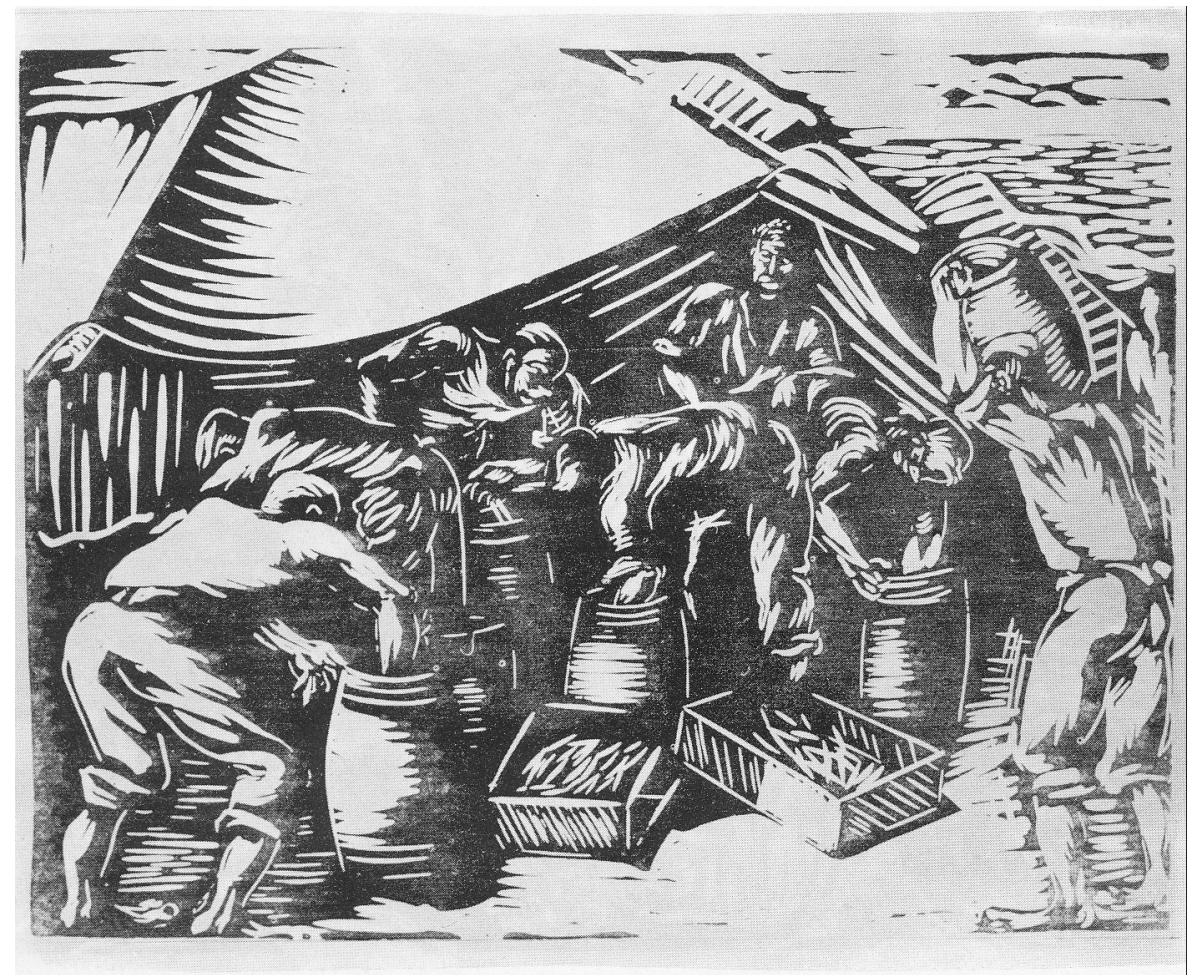

IMAGE NO. 3 MIRKO KUJAČIĆ, THE SUN IS SCORCHING, THE SARDELLA MUST BE BRINED, 20,5 X 26,5, FROM THE MAP “FISHERMEN, WOODPRINT, 1934, PRIVATE PROPERTY.

In the Kingdom of Yugoslavia there were two models of the leftist ideology concepts that were reflected into socially engaged artistic work of the two programmatically declared groups, which were devoted to the engaged form of artistic action: the group "Earth" (1929-1935) from Zagreb (Depolo, 1969, pp. 35-50) and the group "Life" (1932-1940) form Belgrade. On the occasion of the exhibition of the group "Earth in Belgrade" in 1935, the members of 
the group "Life" conducted a great propaganda for this exhibition and organized a meeting with the "Earthlings" in Piperski's studio, where all joint aims were noted, along with all the significant differences between these two groups, in terms of the notional and aesthetic view. In addition to "Earth" dealing with the rural proletariat and "Life" dealing with the deconstruction of the myth of the urban art and urban proletariat, the two groups acted differently toward the dogmatic demands of the Party directives. After Breton's "Second Manifesto" in 1930, there was the occurrence of the polarization between the followers of the Kharkov line and the modernist-individualistic current/fraction influenced by Breton. "Life" will be closer to the Kharkov line, while the "Earthlings" will take side to Krleža's attitudes given in the "Foreword to the Podravian Motifs of Krsta Hegedušić" to whom Marko Ristić will also join, and Radovan Zogović, Milovan Đilas, etc., will be proven as the total opposites (Tešić, 1983, pp. 869-897). Kujačić, Kun, Piperski, Bodnarov, Pijade and the rest considered that the Group was only a member of the Party, whose task was to organize, escort, and direct all its activities, to adapt, to be precise, the general policy of the Party. The Party duplication was far more intense in the leftist literature of that time, then it was in the fine arts, thus the battle against Krleža's "Seal" will be seen as a battle for the notionally-political unity of the Party.

Except for this activity, in 1936 Kujačić, Kun, Beraković, and Bodnarov submitted a resolution on the material status of artists, demanded favorable rent for the exhibition and more equitable policy related to the selection of their artwork for the exhibitions, then they also organized the "Boycott" exhibition directed against the Association "Cvijeta Zuzorić", paving the foundations of the "Independent Artist Showroom", which will be opened in the following 1937.

Members of the group "Life" accepted graphics as the most suitable way of artistic expression, but also as the way of transferring ideas and social program of social art, especially due to the pace of reproduction, as well as clear and appropriate expression. Graphics was considered a very suitable means for educating the masses, it was even called the "avant-garde of the new art" (Ćosić 1969. p. 30). Mirko Kujačić gained artistic reputation primarily as a graphic artist, although his strivings, especially in late years, were pointed toward the domain of painting. At the time of the struggle of graphics for its place in the artistic scene of Belgrade and Yugoslavia, 
Kujačić, together with Kun, found himself amongst their pioneers, who came up with extremely important elements: notional, social content and propaganda purpose. From 1934, his map "Fishermen" originated from the period of life and work among the (neighbor) fishermen on the island of St. Andrija, shortly after he had left his work in the National Theatre in Cetinje, where he worked as the first set designer.

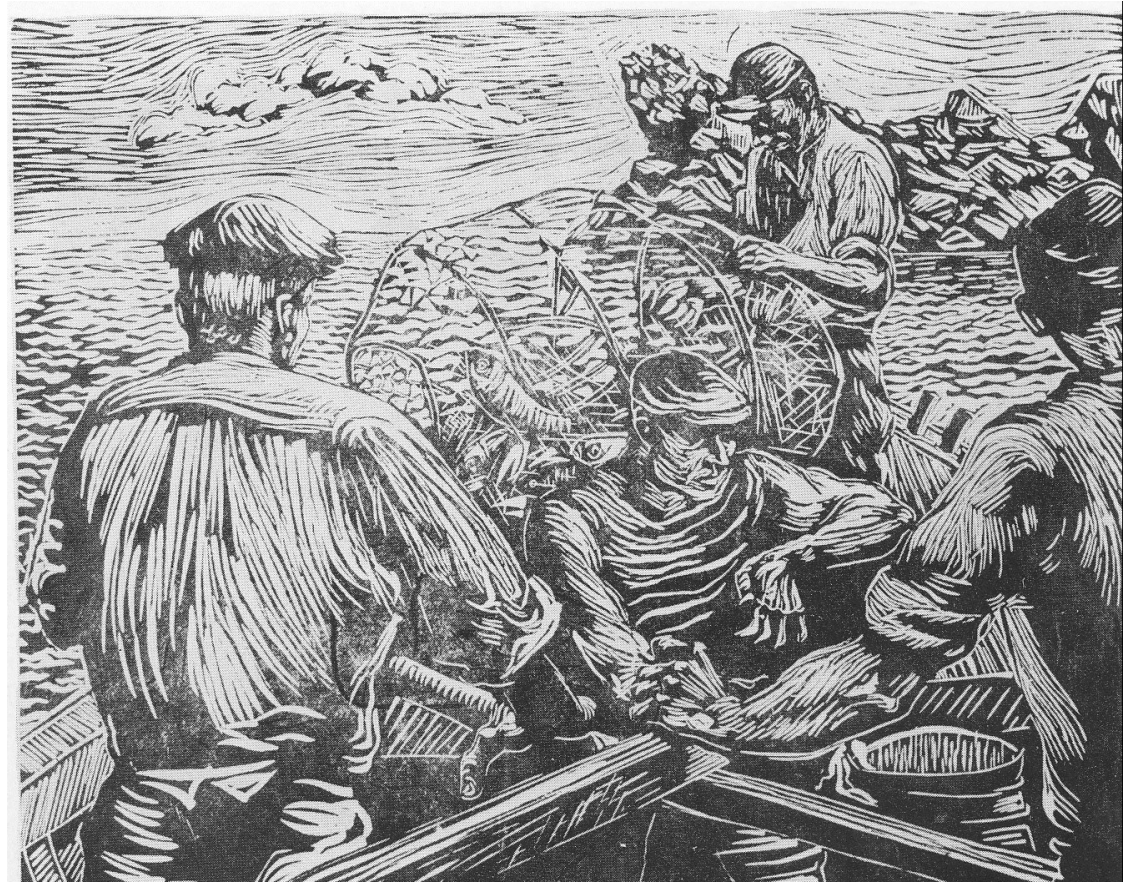

IMAGE NO. 4. MiRKO KUJAČÍ́, THEY ARE COLLECTING COOPS ON HUNTING GROUNDS. 21 X 27. FROM THE MAP "FISHERMEN", WOODPRINT, 1934, PRIVATE PROPERTY.

In 1937, Kujačić returned to Paris, where, on the recommendation of Bora Baruh he found himself amongst the like-minded, under the auspices of the Advanced Youth of France, in "Maison de la culture", whose president was Louis Aragon. There he met many famous painters: Gromer, Fougeron, Frantz Masareel (who was the idol of all socially-colored graphic artists), Lires, Pinon, and other. At the exhibitions organized by "Maison" as the aid for the Spanish children that were victims of war, Picasso, Matisse, Marinetti, Prampolitini, etc., exhibited with our artists, along with Kujačić. The phrase that the painters of "Maison" were gathered around 
was "The Best Communist Painter is the One Who Paints the Best" (Vukotić, 1985, pp. 26-28). Kujačić, together with Baruh, Bodnarov, Seremet, and other painters in Paris at that time, belonged to an advanced student movement of the Marxist orientation, which was the reason for the frequent attacks by the Paris police force (Marjanović, 1964, p. 11). ${ }^{7}$

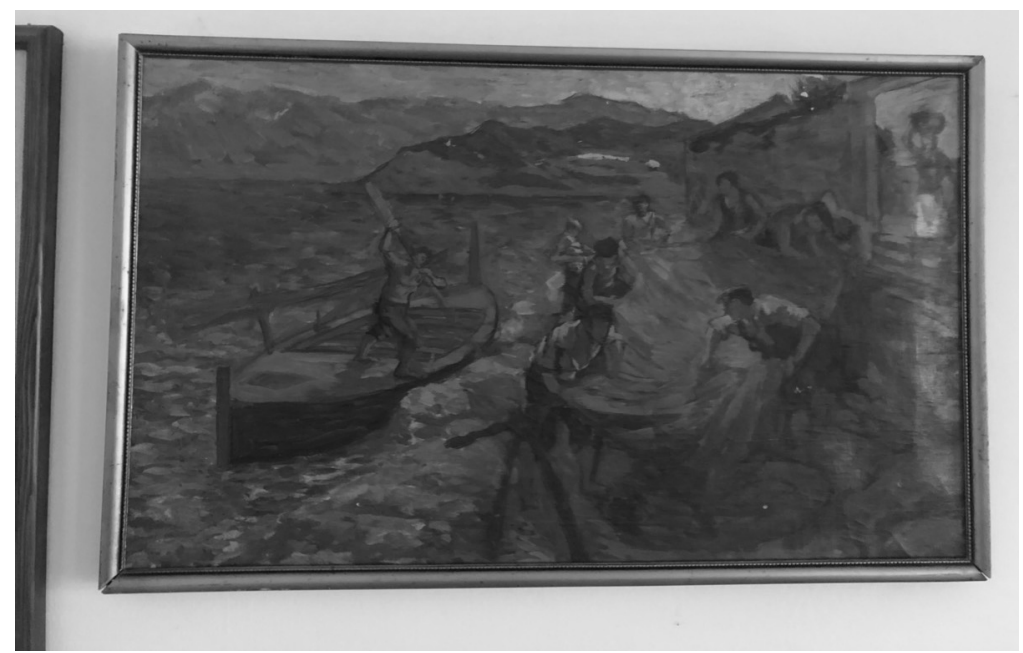

IMAGE NO. 5. MiRKO KUJAČIĆ, FISHERMEN, 35 X 58, OIL PAINTING, NOT DATED (CIRCA 1930?), PRIVATE PROPERTY.

The last public performance of the group "Life" was at the " $13^{\text {th }}$ Autumn Exhibition" in 1940, after which intensified police control was directed against communists and advanced intellectuals, when Đorđe Andrejević Kun was arrested and after which it was no longer safe nor possible to organize the exhibitions or meetings of the illegal group such as the group "Life" (Trifunović, 1983, pp. 245-256).

During the fourth decade of the $20^{\text {th }}$ century, not many paintings with a social tendency were made. Social art in Serbia, however, was not developing only within the framework of the group "Life"

\footnotetext{
In 1938 Bora Baruh was arrested by the Paris police and was deported thhe same year. Similar thing happened 24 years earlier, when following the Sarajevo Assassination, Nadežda Petrović, Branko Radulović, and Laza Drljača were also deported for safety reasons. For additional information on this please see: Марјановић 1964: С. Марјановић, „Бора Барух“, у: Бора Барух кайалої изложће бр. 4, Јајце: Спомен музеј Другог заседања АВНОJ, 11.
} 
and the "Showroom of the Independent" that represented its core, but it also made a breakthrough into the creativity of artists with different tendencies, such as Petar Dobrović, Milan Konjović, Marko Čelebonović and Zora Petrović, and it even found its way to the artwork of Petar Lubarda, which can be seen in its paintings "Workers" and "Shiptar" made in 1935 and 1936. Vinko Grdan also gave great encouragement to social art in Serbia, where, as an "Earthling" he gave a fierce fighting impulse to this kind of painting in Serbia, but from the aspect of harmonization of artistic elements and ideas and exceptional pictorial values of his own paintings. His paintings "Market in Negotin" from 1934, "To the City" from 1935 and "At the Gate" from 1937 are considered the best achievements in the domain of social art in Serbia (Trifunović 1983, pp. 248).

This movement in the Kingdom of Yugoslavia kept pace with Europe where artists gradually became the bearers of the idea of the fight for freedom, justice, and new humane society.

With his contentiousness, self-confidence, but also with great working inquisitiveness, Mirko Kujačić deserves a place among the first ones who encouraged and enabled the breakthrough of social and liberal tendencies into the art of Serbia and the Kingdom of Yugoslavia.

\section{LIST OF ILLUSTRATIONS}

Image no. 1. Mirko Kujačić, Self-portrait, 46 x 37, woodprint, not dated, private property.

Image no. 2. Mirko Kujačić, There is no such thing as a free lunch, 18,5 x 25, woodprint, 1933, private property.

Image no. 3. Mirko Kujačić, The Sun is scorching, the sardella must be brined, from the map "Fishermen", 20,5 x 27, woodprint, 1934, private property.

Image no. 4. Mirko Kujačić, They are collecting coops on hunting grounds, from the map "Fishermen", 21 x 27, woodprint, 1934, private property.

Image no. 5. Mirko Kujačić, "Fishermen", 35 x 58, oil painting, not dated (circa 1930?), private property.

\section{REFERENCES}

Аноним (1926, 16. новембар). Рабиндранат Тагоре у Београду. Политика, стр. 5. 
Аноним (1926, 17. новембар). Београђани одушевљено поздрављају великог индијског песника. Два предавања г. Рабиндраната Тагора. Политика, стр. 6.

Breton, A. (1979). Tri manifesta nadrealizma, Kruševac: Bagdala.

Вукотић, М. (1985, год. XVII бр. 198). Нова авангарда у старом закашњењу. Разговор са Мирком Кујачићем. ОВДЈЕ, стр. 26-28.

Depolo, J. (1969). Socijalna umetnost u Srbiji. U: M. B. Protić (prired. i ur.), Jugoslovenska umetnosti XX veka. 1929-1950: Nadrealizam. Socijalna umetnost (35-50). Beograd: Muzej savremene umetnosti.

Dedić, N. (2012). Socijalni realizmi: ka postavangardnoj kritici društva. U: M. Šuvaković (prir. i ur.), Istorija umetnosti u Srbiji XX veka. Realizmi i modernizmi oko hladnog rata, drugi tom (77-98). Beograd: Orion Art.

Lasić, S. (1970). Sukobi na književnoj ljevici 1928-1952. Zagreb: Liber.

Мирски, Ф. (1926, 15. новембар). Индијски национализам. Поводом доласка г. Рабиндранат Тагоре. Политика, стр.4.

Marjanović, S. (1964). Bora Baruh. U: Bora Baruh katalog izložbe br. 4 (str. 11). Jajce: Spomen muzej II zasedanja AVNOJ.

Марковић, С. (2009). Децемठарска група, Београд: Институт за историју уметности Филозофског факултета Универзитета у Београду.

Mitrović, A. (1983). Angažovano i lepo.Umetnost u razdoblju svetskih ratova (1914-1945). Beograd: Narodna Knjiga.

Н. J. (1932, 25. априла). На средини ठелог платна прикачена стара цокула. Политика, стр. 7.

Петровић, Р. (1932, 26. април). Сташа Беложански и Мирко Кујачић, сликари. Политика, стр. 7.

Protić, M. (1971). Četvrta decenija: ekspresionizam boje, poetski relizam, intimizam, koloristički realizam“. U: M. B. Protić (prir. i ur.), Jugoslovenska umetnost XX veka. Čevrta decenija. Ekspresionizam boje, poestki realizam (7-13). Beograd: Muzej savremene umetnosti.

Rozić, V. (1983). Likovna kritika u Beogradu između dva rata (1918-1941), Beograd:Jugoslavija.

Tešić, G. (1983). Zli volšebnici. Polemike i pamfleti u srpskoj književnosti 1917-1943, knj. 3. Beograd: Slovo ljubve, Beogradska knjiga Matica srpska.

Трифуновић, Л. (1967). Српска ликовна критика. Избор, Београд: Српска књижевна задруга.

Трифуновић, Л. (1973). Српско сликарство 1900-1950, Београд: Нолит. 
Ћетковић, В. (1991). Социјална уметност у Србији између два рата. Нови Сад: Академија уметности у Новом Саду.

Ćosić, В. (1969). Socijalna umetnost u Srbiji. U: M. B. Protić (pripr. i ur.), Jugoslovenska umetnosti XX veka. 1929-1950: Nadrealizam. Socijalna umetnost (24-35). Beograd: Muzej savremene umetnosti.

Šuvaković, M. (2009). Teorija i praksa avangarde. U: M. Šuvaković (prir. i ur.), Istorija umetnosti u Srbiji XX veka. Radikalne umetničke prakse, prvi tom (53-63). Beograd: Orion Art.

Šuvaković, M. (2010). Avangarde u Jugoslaviji i Srbiji. U: M. Šuvaković (prir. i ur.), Istorija umetnosti u Srbiji XX veka. Radikalne umetničke prakse, prvi tom (63-74). Beograd: Orion Art.

Šuvaković, M. (2012). Desne opcije i socijlana umetnost pred Drugi svetski rat. U: M. Šuvaković (prir. i ur.), Istorija umetnosti u Srbiji XX veka. Realizmi i modernizmi oko hladnog rata, drugi tom (41-76). Beograd: Orion Art.

СРЂАН Д. МАРКОВИЋ

УНИВЕРЗИТЕТ У НИШУ

ФАКУЛТЕТ УМЕТНОСТИ

МАРТА М. ВУКОТИЋ ЛАЗАР

УНИВЕРЗИТЕТ У ПРИШТИНИ СА ПРИВРЕМЕНИМ СЕДИШТЕМ

У КОСОВСКОЈ МИТРОВИЦИ, ФИЛОЗОФСКИ ФАКУЛТЕТ

РЕЗИМЕ

МИРКО КУЈАЧИЋ И СОЦИЈАЛНА УМЕТНОСТ У СРБИЈИ

Сажетак. Уметност четврте деценије XX века, која као да је и сама најављивала Други светски рат, била је поларизована између тзв. „чисте уметности“ (l'art pour l'art), ангажоване уметности (l'art pour l'idée) и борбеног реализма. Ова одвојеност често је проузроковала идеолошке сукобе који су се заоштравали и прелазили у сферу политичких сукоба. Два модела левих идеолошких концепата огледају се у социјално ангажованом уметничком раду две програмско декларисане групе које су се залагале за ангажовани облик уметничког деловања: групе „Земља“ (1929-1935) из Загреба и групе „Живот“ (1932-1940) из Београда.

Социјална уметност у Србији имала је снажне зачетке у другој половини треће деценије двадесетог века и протезала се кроз период ратних дешавања до 1943. године. У периоду између два светска рата почиње Манифестом Мирка Кујачића (1901-1987) објављеним 1932. године и изложбом његових надреалистичких колажа, урамљене цокуле, објекта под називом „Зимски мотив“ 
и њеног пандана, слике под називом „Корен ठеоградске отмености“. Важан догађај за наставак оваквих уметничких тенденција је формирање групе „Живот“ 1934. године у Београду, чији је Кујачић био један од оснивача и главних протагониста.

КљУчнЕ РЕчИ: југословенска савремена уметност; социјална уметност; графика; сликарство; „Живот“; „Земља“; србија.

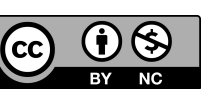

Овај чланак је објављен и дистрибуира се под лиценцом Creative Commons Ауторство-Некомерцијално Међународна 4.0 (CC BY-NC 4.0 |

https://creativecommons.org/licenses/by-nc/4.0/).

This paper is published and distributed under the terms and conditions of the Creative Commons Attribution-NonCommercial International 4.0 licence (CC BY-NC 4.0 | https://creativecommons.org/licenses/by-nc/4.0/). 